\title{
Middle latency auditory evoked potential in child population
}

\author{
Anna Caroline Silva de Oliveira ${ }^{1}$, Simone Fiuza Regaçone $^{1}$, Ana Claudia Figueiredo Frizzo ${ }^{1}$
}

DOI: http://dx.doi.org/10.7322/jhgd.122905

\begin{abstract}
:
Introduction: The middle-latency auditory evoked potential is used to evaluate any abnormality that might impair the central auditory pathways, which are situated between the brain stem and the primary auditory cortex.

Objective: To analyse the middle-latency auditory evoked potentials in children.

Methods : This is a descriptive and cross-sectional study. Pure-tone audiometry was performed, and if no change was detected, Biologic's portable Evoked Potential System (EP) was used to measure auditory evoked potentials. The identification of the responses was performed using electrodes positioned at C3 and C4 (left and right hemispheres) in reference to ears A1 and A2 (left and right earlobe). These were ipsilaterally and contralaterally paired and landed at Fpz (forehead), in two steps, with alternating stimulation of the right and left ears.
\end{abstract}

Results: In this study, there was $100 \%$ detectability of the $\mathrm{Na}, \mathrm{Pa}$, and $\mathrm{Nb}$ components and interamplitude $\mathrm{Na}-\mathrm{Pa}$. This study compared different electrode leads, and there was no significant difference between the different electrode positions studied for the right and left ears in the studied population.

Conclusion: It was concluded that the examination of middle-latency evoked potential is steady and feasible for the studied age group regardless of electrode position.

Keywords: auditory evoked potential; auditory evoked responses; children.

\section{INTRODUCTION}

Middle-latency Auditory Evoked Potentials (MLAEP) are bioelectric responses captured by electrodes placed at specific regions on the surface of the head, occurring between 10 and $80 \mathrm{~ms}$ after the sound stimulus, and comprise a series of waves of negative voltage represented by the letter $\mathrm{N}$ and positive voltage represented by the letter P. In general, MLAEP responses are analysed in milliseconds for wave latencies and in microvolts for amplitude. Latency corresponds to the speed of auditory processing along the pathway; as for amplitude, it is the electrical activity at the cortex level generated as a result of auditory stimulation ${ }^{1,2}$.

The first major negative peak that appears, $\mathrm{Na}$, is found between 12 and $27 \mathrm{~ms}$, and then the highest positive peak, $\mathrm{Pa}$, is presented between 25 and $40 \mathrm{~ms}$, and $\mathrm{Nb}$ is the negative peak after $\mathrm{Pa}$, between 30 and $55 \mathrm{~ms}$, according to the normal range ${ }^{3}$.

The most used measure in response analysis is $\mathrm{Na}-\mathrm{Pa}$ waves inter amplitude ${ }^{4,5}$. In typical individuals, in general, $\mathrm{Na}-\mathrm{Pa}$ wave amplitude values are symmetrical, i.e., electrodes placed on the right and left temporal lobe should show similar responses. Wave analysis should be carried out on a comparative observation of the right ear (RE) and left ear (LE), and the right and left hemispheres to determine normality, analysing what is named ear and electrode effects ${ }^{6}$.

The clinical application of MLAEP is used in the evaluation of any abnormality that could impair the central auditory pathways, situated between the brain-colliculus lower trunk and the primary auditory cortex ${ }^{7}$. Gução et al, $(2014)^{8}$ confirmed this hypothesis and concluded, in their study, that there was a change in the functioning of

1 Faculdade de Filosofia e Ciências - FFC UNESP - Marília (SP), Brasil.

Corresponding author: Ana Claudia Figueiredo Frizzo - e-mail: anafrizzo@marilia.unesp.br

Suggested Citation: Oliveira ACS, Regaçone SF, Frizzo ACF. Middle Latency Auditory Evoked Potential in child population. J Hum Growth Dev. 2016; 26(3): 368-373. DOI: http://dx.doi.org/10.7322/jhgd.122905

Manuscript submitted 9 May 2016, accepted for publication 16 Jun 2016. 
the auditory information to the cortex level in two children with Asperger Syndrome.

Auditory Evoked Potentials have effectively contributed in the knowledge of normal and deviant auditory processing, and assisted health professionals in determining diagnosis and proper therapeutic treatment.

Adults and children with language, speech and learning disorders have been evaluated in MLAEP studies. This exam has shown to be the most appropriate method for the objective evaluation of auditory pathways integrity since MLAEP have higher neural origins ${ }^{9}$.

In Brazil, studies have been conducted using MLAEP in clinical conditions such as auditory processing disorder central ${ }^{10}$, aphasia ${ }^{11}$, human immunodefi ciency caused by HIV virus ${ }^{12-13}$ Landau-Kleffner syndrome ${ }^{14}$, Multiple Sclerosis ${ }^{15}$, showing latency and amplitude changes in these conditions inherent to dysfunctions of central auditory pathways.

MLAEP is used for more accurate diagnosis of changes that affect the auditory pathway, especially in paediatric populations. In the literature, studies investigating healthy populations are restricted ${ }^{16-17}$, therefore, it is important to carry out further studies to obtain standards and criteria for identifying waves and the parameters used in MLAEP examination in normal children. In this context, the aim of this study is to analyse the MLAEP in children.

\section{METHODS}

This is a descriptive, analytical and cross-sectional study. It was conducted with the approval of the Research Ethics Committee, under number 2013-673, and those responsible for the study participants signed an informed consent and prior to data collection.

We analysed 20 schoolchildren, apparently healthy, of both sexes, aged from 8 to 13 years (mean age of 10.4 years and standard deviation of 1.6 years).

As inclusion criteria, we selected apparently healthy children, with no complaints of school learning disorders, and with auditory thresholds within normal standards ${ }^{18}$.

Initially, the teachers of several elementary schools selected the children with good performance in Portuguese and Mathematics in two consecutive marking periods. Then, neurological evaluation was performed to rule out any impairment in this area, in addition to collecting the children's history to investigate general health and hearing conditions.

Subsequently, inspection of the external auditory canal was performed to verify excess of cerumen, and to carry out basic audiological evaluation, composed by pure-tone audiometry in frequencies from 250 to 8000 $\mathrm{Hz}$, and to be included as participant, the children should have thresholds below or equal to $25 \mathrm{~dB}^{18}$, immitanciometry with type A tympanometric curve, indicating normal mobility of the tympanic-ossicular system ${ }^{19}$ and present ipsilateral and contralateral reflexes.

For MLAEP identification, we used the two-channel equipment Biologic's Evoked Potential
System (EP) and 3A insert earphones. All subjects were accommodated in a sound insulation enclosure, and controlled temperature at $24^{\circ} \mathrm{C}$, positioned in a reclining chair, they were required to remain relaxed with their eyes open and to stay alert.

The electrodes were fixed with adhesive tape microporous after cleaning the skin with abrasive paste; we also used electrolytic paste to improve the electrical conductivity. The impedance of each electrode did not exceed 5 Kohms and did not exceed 2 Kohms between the electrodes impedance ${ }^{3}$.

For the identification of MLAEP, we used monaural clicks stimuli rarefied at $70 \mathrm{~dB} \mathrm{HL}$ at $100 \mathrm{~ms}$ duration, with presentation rate of 11 stimuli/second, analysis time (window) of $100 \mathrm{~ms}$, acoustic filter from 10 to $100 \mathrm{~Hz}$, amplification of 75.000x.

MLAEP responses were obtained through the electrode leads and divided in two acquisition groups, according to the stimulated ear. The first identification was carried out during the acoustic stimulation of the right ear and divided into two steps. In the first step, the electrodes were placed as follows: active electrodes $(+)$ at $\mathrm{C} 3$ (left hemisphere) and at $\mathrm{C} 4$ (right hemisphere); and the reference electrode (-) at A2 (right earlobe); and land at Fp (forehead). In the second step, we changed the position of the reference electrode to A1 (left earlobe) (Figure 1).

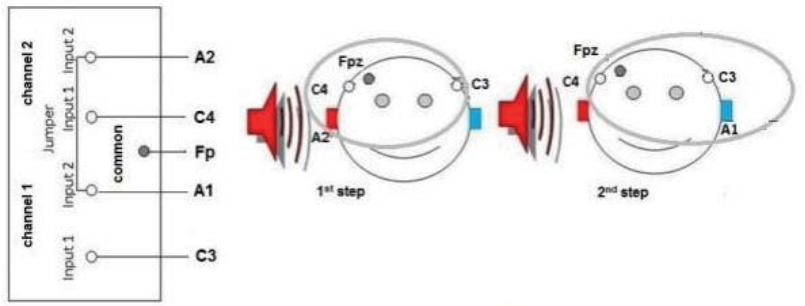

Figure 1 - Electrodes position - 1st identification. 1st step: the gray circle refers to the electric field formed with the electrodes positioned at C4/A2 and C3/A2 during acoustic stimulation of the right ear. 2nd step: the gray circle refers to the electric field formed with the electrodes positioned at C3/A1 e C4/A1 during acoustic stimulation of the right ear.

Caption: Fpz: common electrode placed to the right of forehead; C4: electrode placed at the right temporoparietal lobe; C3: electrode placed at the left temporoparietal lobe; A2: reference electrode placed at the right earlobe; $A 1$ : reference electrode placed at the left earlobe.

The second identification was performed during the acoustic stimulation of the left ear and also divided into two steps. In the first step, the electrodes were placed as follows: active electrodes (+) at C3 (left hemisphere) and at $\mathrm{C} 4$ (right hemisphere); and the reference electrode (-) at A1 (left earlobe); and land at Fp (forehead). In the second step, the reference electrode was positioned at A2 (right earlobe) (Figure 2).

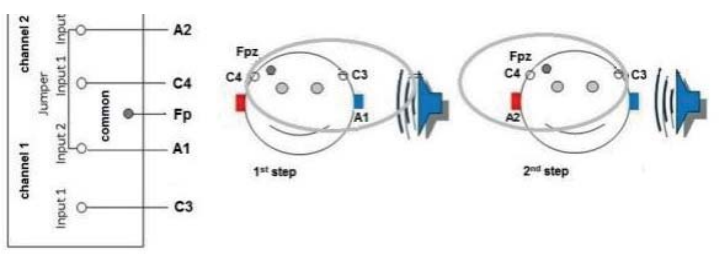

Figure 2 - Electrodes Position - 2nd identification. 1st step: the gray circle refers to the electric field formed with the electrodes positioned at C3/A1 and C4/A1 during acoustic stimulation of the left ear. 2 nd step: the gray circle refers to the electric field formed with 
the electrodes positioned at C4/A2 and C3/A2 during acoustic stimulation of the left ear.

Caption: Fpz: common electrode placed to the right of forehead; C4: electrode placed at the right temporoparietal lobe; C3: electrode placed at the left temporoparietal lobe; A2: reference electrode placed at the right earlobe; $\mathrm{A} 1$ : reference electrode placed at the left earlobe.

The components analysed in the MLAEP study were: $\mathrm{Na}$, which corresponds to the first highest negative peak between 12 and $27 \mathrm{~ms}$; Pa, the most positive peak after $\mathrm{Na}$, between 25 and $40 \mathrm{~ms}$, the most prominent among the waves which can be compared to the $\mathrm{V}$ wave of Brainstem Auditory Evoked Potential; and Nb, the negative peak after $\mathrm{Pa}$, formed between 30 and $55 \mathrm{~ms}$, after acoustic stimulation as first analysis. Interamplitude was also analysed between $\mathrm{Na}$ and $\mathrm{Pa}(\mathrm{Na}-\mathrm{Pa})$ component ${ }^{3}$.

For the analysis of inter-subject interamplitude, the responses from one side or the other that did not exceed $50 \%$ in the same individual were considered with no abnormality in this sensory modality ${ }^{20}$.

For inferential statistical analysis of data, we initially determined data normality through Shapiro-Wilk test. Following, we performed the comparison of the results by analysing the variations in relation to the stimulation of the right and left ears according to the electrodes position, contralateral and ipsilateral. Student's t-test was used for stimulation comparison between the different stimulation identification leads.

The differences in the identifications were considered statistically significant when the $\mathrm{p}$ value was lower than $0.05(5 \%)$. The statistical program we used was Bioestat 2009 Professional 5.8.4 Software version 2.00 for Windows.

\section{RESULTS}

Latencies of components $\mathrm{Na}, \mathrm{Pa}, \mathrm{Nb}$ and $\mathrm{Na}-\mathrm{Pa}$ interamplitude were studied. The tables describe latency and amplitude times, and the calculated average values, standard deviation and $p$ values of the variables.

The results of this descriptive and inferential analysis are shown in Tables 1 and 2, as follows:

Table 1: Descriptive and inferential statistical analysis of MLAEP for the $1^{\text {st }}$ identification

\begin{tabular}{lccccc} 
Variables & $\begin{array}{c}\text { C3A1 } \\
\text { Mean }\end{array}$ & $\begin{array}{c}\text { C3A2 } \\
\text { SD }\end{array}$ & Mean & SD & P value* \\
\hline Na RE & 20,239 & 3,889 & 18,938 & 3,757 & 0,144 \\
PA RE & 34,480 & 5,231 & 33,501 & 4,668 & 0,400 \\
Nb RE & 50,121 & 5,288 & 50,116 & 5,448 & 0,490 \\
Na-Pa RE & $-1,242$ & 0,783 & $-1,123$ & 0,528 & 0,280 \\
& C4A1 & C4A2 & & & \\
& Mean & SD & Mean & SD & P value* \\
Na RE & 19,291 & 3,220 & 19,561 & 5,050 & 0,420 \\
Pa RE & 30,702 & 8,465 & 33,636 & 8,407 & 0,130 \\
Nb RE & 47,930 & 10,355 & 47,305 & 6,810 & 0,410 \\
Na-Pa RE & $-1,197$ & 0,534 & $-1,070$ & 0,430 & 0,200 \\
\hline
\end{tabular}

Caption: RE: right ear; SD: Standard Deviation, C3: left hemisphere; C4: right hemisphere; A1: left earlobe; A2: right earlobe; * $p \leq 0,05$.

MLAEP: Middle Latency Auditory Evoked Potential.

Table 2: Descriptive and inferential statistical analysis of MLAEP for the $2^{\text {st }}$ identification

\begin{tabular}{|c|c|c|c|c|c|}
\hline Variables & $\begin{array}{l}\text { C3A1 } \\
\text { Mean }\end{array}$ & $\begin{array}{c}\text { C3A2 } \\
\text { SD }\end{array}$ & Mean & SD & P value* \\
\hline $\begin{array}{l}\text { Na LE } \\
\text { PA LE } \\
\text { Nb LE } \\
\text { Na-Pa LE }\end{array}$ & $\begin{array}{l}18,977 \\
33,012 \\
46,336 \\
-0,975\end{array}$ & $\begin{array}{l}3,737 \\
5,013 \\
6,096 \\
0,526\end{array}$ & $\begin{array}{r}19,385 \\
30,545 \\
45,879 \\
-1,025\end{array}$ & $\begin{array}{l}4,349 \\
5,912 \\
6,627 \\
0,534\end{array}$ & $\begin{array}{l}0,370 \\
0,130 \\
0,410 \\
0,380\end{array}$ \\
\hline & $\begin{array}{l}\text { C4A1 } \\
\text { Mean }\end{array}$ & $\begin{array}{c}\text { C4A2 } \\
\text { SD }\end{array}$ & Mean & SD & P value* \\
\hline $\begin{array}{l}\mathrm{Na} \text { LE } \\
\mathrm{Pa} \text { LE } \\
\mathrm{Nb} \text { LE } \\
\mathrm{Na}-\mathrm{Pa} \text { LE }\end{array}$ & $\begin{array}{l}20,373 \\
33,398 \\
48,606 \\
-1,276\end{array}$ & $\begin{array}{l}4,283 \\
6,094 \\
9,655 \\
0,592\end{array}$ & $\begin{array}{c}19,249 \\
32,876 \\
50,812 \\
-1,211\end{array}$ & $\begin{array}{c}4,354 \\
6,196 \\
8,380 \\
0,631\end{array}$ & $\begin{array}{l}0,200 \\
0,390 \\
0,220 \\
0,370\end{array}$ \\
\hline
\end{tabular}

Caption: LE: left ear; SD: Standard Deviation, C3: left hemisphere; C4: right hemisphere; A1: left earlobe;

A2: right earlobe; * $p \leq 0,05$.

MLAEP: Middle Latency Auditory Evoked Potential. 
It was possible to analyse MLAEP components across all the studied population. When comparing the identifications, ipisilateral and contralateral, obtained through stimulation in the right ear (Table 1) as well as through stimulation in the left ear (Table 2), we observed no statistically significant difference.

\section{DISCUSSION}

It was observed that the latencies of $\mathrm{Na}, \mathrm{Pa}$ and $\mathrm{Nb}$ and interlatency $\mathrm{Na}-\mathrm{Pa}$ showed average values, appropriate for chronological age, according to the literature. In general, $\mathrm{Na}$ is observed between 12 and $27 \mathrm{~ms}$; $\mathrm{Pa}$ is the highest positive peak after $\mathrm{Na}$, between 25 and $40 \mathrm{~ms}$; $\mathrm{Nb}$ is the negative peak after $\mathrm{Pa}$, between 30 and $55 \mathrm{~ms}^{3,21-22}$. The average Pa-interamplitude value of the studied population is also consistent with the literature, between $0.5 \mu \mathrm{V}$ and $2.0 \mu \mathrm{V}^{20}$ and between $0.4 \mu \mathrm{V}$ and $2.58 \mu \mathrm{V}$ for the age group ${ }^{16,23}$.

MLAEP components have multiple neural generators that undergo a maturation process reporting distinct neural development courses. For example, from childhood to adolescence, detection of $\mathrm{Pa}$ wave is increased. In children, the values of latency and amplitude become similar to those of adults when they are close to 10 years old ${ }^{24}$. In this study, we studied children from 08 years old, and $\mathrm{Na}, \mathrm{Pa}$ and $\mathrm{Nb}$ waves were detected in all children studied with average values similar to those described in the literature for the 10-year-old age group.

Among the components, the $\mathrm{Nb}$ average value is the only one with a greater variation in the average value established for children ${ }^{16,23}$, which can be explained by the fact that $\mathrm{Nb}$ component is generated in an upper region of the auditory pathway - auditory associative pathway ${ }^{7,9}$ with later maturation, therefore the diffi culty in establishing a standard value.

We found, in some studies ${ }^{19,24}$, that the results in normal hearing subjects are also changed depending on the maturation level, possibly due to neural generators of the components analysed in MLAEP still developing until late adolescence. Therefore, the auditory pathway maturation may affect this MLAEP response, which would justify studies of this scope in different age group populations.

There is currently no consensus among Brazilian studies using MLAEP regarding the optimal methodology for electrode position and analysis of the MLAEP response. Mostly, in national studies, when the right ear is stimulated, the electrodes are placed at $\mathrm{C} 3$ and $\mathrm{C} 4$ (left and right hemispheres) $(+)$ with reference in A2 ears (right ear lobe) (-), and ground at Fp (forehead), paired, ipsilateral of the right side and contralateral to the right. When the left ear is stimulated, in general, the electrodes are positioned at $\mathrm{C} 3$ and $\mathrm{C} 4$ (left and right hemispheres) $(+)$ with references electrode in A1 ears (left ear lobe) (-) and ground electrode at Fp (forehead), paired, ipsilateral and contralateral to the left $\mathrm{ft}^{25}$.

Other studies ${ }^{28-31}$ identified the electrical signals from an electrode at the midline $(\mathrm{Cz})$ referred to the ipsilateral ear in an identification channel, and the contralateral earlobe in another channel, and the ground electrode (Fp) positioned on the forehead. This arrangement is limited to ear effect comparison - right and left stimulation focused only in the diagnosis of central auditory pathway disorders.
Electrodes must be placed on each hemisphere and not only on the vertex $(\mathrm{Cz})$ to optimize the application. The electrode placed at the site of injury or dysfunction provides the best indication of a possible deficit ${ }^{32}$. Moreover, the identification of the electrical activity of proximal field used in this kind of potential allows capturing the direct fl ow of electrical charges between the depolarization and repolarization area if placed near the auditory neural generating area, which generates large amplitudes with good visualization, even with the attenuation of the scalp and cranial bones and tissues ${ }^{33}$.

MLAEP research using ipsilateral and contralateral identifications allows comparison of the two hemispheres and two ears, in addition to provide the diagnosis of injuries and disorders of central auditory pathways, and the different types of identifications can sensitize the assessment ${ }^{34-35}$.

Furthermore, in children, due to neuromaturation in full development, functional age-related differences have characterized the nature of $\mathrm{Na}-\mathrm{Pa}$ interamplitude responses. Ear and hemisphere effects have been identified in this population even in conditions of typical development of auditory system due to the maturational process ${ }^{5,23-25}$.

Two neural circuits are involved in the generation of MLAEPs. Due to the neural development of these systems, capturing MLAEP is directly related to the age of the evaluated subject. One neural circuit develops earlier, and is a portion of the subcortical auditory pathway. The second circuit takes longer to develop, and is part of the primary and secondary auditory pathway. The development of primary and secondary neural generator varies across individuals, but cannot be developed until adulthood.

In this study, the authors were motivated by the possibility of having an electrode arrangement that could improve the observation of the responses of the contralateral central auditory pathways. This evaluation aimed at proposing to broaden and specify the study of the responses, and also to enable the analysis of neurotransmission at the level of associative cortical pathways through the analysis of contralateral identifications in child populations.

The components of MLAEP interest were analysed in the study population regardless of identification performed. However, no differences were observed when comparing the ipsilateral and contralateral measures in the population of children with typical hearing development, which encourages authors suggest the use of these electrodes leads in clinical practice.

However, a limitation of this study is that these findings apply only to the age group studied here, since this population is in the auditory pathway maturational process and differences can be found in other age groups. Moreover, for a more thorough analysis we suggest using an equipment with more identification channels, which allow the analysis of other auditory cortical areas.

\section{CONCLUSION}

We concluded that the examination of MLAEP responses is stable. MLAEP responses represent a viable measure for the age group, regardless of electrode position. 
1. Geisler CD, Frishkopf LS, Rosenblith WA. Extracranial responses to acoustic clicks in man. Science. 1958;128(3333):1210-11. DOI: http://dx.doi.org/10.1126/science.128.3333.1210

2. Ruth RA, Lambert PR. Auditory evoked potentials. Otolaryngol Clin North Am. 1991;24(2):349-70.

3. Hall J. Handbook of auditory evoked responses. Boston: Allyn \& Bacon; 2006.

4. Musiek FE, Lee WW. Potenciais Auditivos de Média e Longa Latência. In: Musiek FE, Lee WW. Perspectivas atuais em avaliação auditiva. São Paulo: Manole; 2001; p. 8.

5. Weihing J, Schochat E, Musiek F. Ear and electrode effects reduce within-group variability in middle latency response amplitude measures. Int J Audiol. 2012;51(5): 405-12. DOI: http://dx.doi.org/10.3 109/14992027.2012.658970

6. Simões MB, Souza RR, Schochat E. Efeito da supressão nas vias auditivas: um estudo com os potenciais de média e longa latência. Rev CEFAC. 2009;11(1): 150-7. DOI: http://dx.doi.org/10.1590/S151618462008005000011

7. Munhoz MSL. Respostas Auditivas de Média Latência. In: Munhoz MSL, Caovil HH. Audiologia Clínica Volume 2. São Paulo: Editora Atheneu; 2000.

8. Gução ACB, Romero ACL, Valenti VE, Cardoso ACV, Misquiatti ARN, Frizzo ACF. Auditory Late Responses in Asperger Syndrome: two case study. J Hum Growth Dev. 2014;24(1):49-53. DOI: http://dx.doi. org/10.7322/jhgd.72092

9. Arehole S, Augustine L, Simhadri R. Midlle latency responses in children with learning disabilities: pre-liminary findings. J Commun Disord. 1995;28(1):21-38. DOI: http://dx.doi.org/10.1016/0021-9924(94)00004-J

10. Schochat E, Musiek FE, Alonso R, Ogata J. Effect of auditory training on the middle latency response in children with (central) auditory processing disorder. Braz J Med Biol Res. 2010; 43(8):777-85. DOI. http:// dx.doi.org/10.1590/S0100-879X2010007500069

11. Alvarenga KF, Lamônica DC, Costa Filho OA, Banhara MR, Oliveira DT, Campo MA. Estudo eletrofisiológico do sistema auditivo periférico e central em indivíduos afásicos. Arq Neuropsiquiatr. 2005;63(1):104-9. DOI: http://dx.doi.org/10.1590/S0004-282X2005000100019

12. Frias VAC, Cárnio MS, Matas CG, Leite RA, Carvalho RMM, Neves IF. Distúrbios de leitura e escrita em portadora do vírus da imunodeficiência humana: estudo de caso. Rev Soc Bras Fonoaudiol. 2008;13(2):17985. DOI: http://dx.doi.org/10.1590/S1516-80342008000200013

13. Matas CG, Juan KR, Nakano RA. Potenciais evocados auditivos de média e longa latência em adultos com AIDS. Pró-Fono Rev Atual Cient. 2006;18(2):171-6. DOI: http://dx.doi.org/10.1590/S010456872006000200006

14. Matas CG, Gonçalves IC, Magliaro FCL, Leite RA, Guilhoto LMFR. Avaliação audiológica e eletrofisiológica da audição na Síndrome de Landau-Kleffner. Rev Soc Bras Fonoaudiol. 2007;12(2):79-85. DOI: http:// dx.doi.org/10.1590/S1516-80342007000200003

15. Matas CG, Matas SLA, Oliveira CRS, Gonçalves IC. Potenciais evocados auditivos e esclerose múltipla. Arq Neuropsiquiatr. 2010;68(4):528-34. DOI: http://dx.doi.org/10.1590/S0004-282X2010000400010

16. Luo JJ, Khurana DS, Kothare SV. Brainstem auditory evoked potentials and middle latency auditory evoked potentials in young children. J Clin Neurosci. 2013;20(3):383-8. DOI: http://dx.doi.org/10.1016/j. jocn.2012.02.038

17. Frizzo ACF, Funayama CAR, Isaac ML, Colafêmina JF. Potenciais Evocados Auditivos de Média Latência: estudo em crianças saudáveis. Rev Bras Otorrinolaringol. 2007;73(3):398-403. DOI: http:// dx.doi.org/10.1590/S0034-72992007000300016

18. Kaplan H, Gladstone V, Lloyd L. Audiometric interpretation: a manual o basic audiometry. Baltimore: Allyn \& Bacon; 1993.

19. Jerger J. Clinical experience with impedance audiometry. Arch Otolaryngol. 1970; 92(4):311-24. DOI: http://dx.doi.org/10.1001/archotol.1970.04310040005002

20. Musiek FE, Baran JA, Pinheiro ML. Neuroaudiology: case studies. San Diego: Singular; 1994; p. 279.

21. Pratt H. Middle-Latency Response. In Burkard RF, Don M, Eggermont JJ. Auditory Evoked Potentials: basic principles and clinical application. Baltimore: Lippinccott Williams \& Wilkins. 2007; p.463-81.

22. Musiek FE, Geurkink NA, Weider DJ Donnelly K. Past, present, and future applications of the auditory middle latency response. Laryngoscope. 1984;94(12 Pt 1):1545-53. DOI: http://dx.doi.org/10.1288/00005537198412000-00002

23. Neves IF, Gonçalves IC, Leite RA, Magliaro FCL, Matas CG. Estudo das latências e amplitudes dos potenciais evocados auditivos de média latência em indivíduos audiologicamente normais. Rev Bras Otorrinolaringol. 2007;73(1):75-80. DOI: http://dx.doi.org/10.1590/S0034-72992007000100012

24. Kraus N, Smith DI, Reed NL, Stein LK, Cartee C. Auditory middle latency responses in children: Effects of age and diagnostic category. Electroencephalogr Clin Neurophysiol. 1985;62(5):343-351. DOI: http:// dx.doi.org/10.1016/0168-5597(85)90043-7

25. Tsurukiri J, Nagata K, Okita T, Oomura T. Middle latency auditory-evoked potential index for predicting 
the degree of consciousness of comatose patients in EDs. Am J Emerg Med. 2013;31(11):1556-9. DOI: http://dx.doi.org/10.1016/j.ajem.2013.06.012

26. Magliaro FCL, Scheuer Cl, Assumpção Júnior FB, Matas CG. Estudo dos potenciais evocados auditivos em autismo. Pró-Fono Rev Atual Cient. 2010;22(1):31-6. DOI: http://dx.doi.org/10.1590/S010456872010000100007

27. Almeida FS, Pialarissi PR, Paiva Júnior LEF, Almeida MAO, Silva A. Respostas Auditivas Evocadas de Latência Média: Um estudo de padronização. Rev Bras Otorrinolaringol. 2006; 72(2):227-34. DOI: http:// dx.doi.org/10.1590/S0034-72992006000200013

28. Al-Saif SS, Abdeltawwab MM, Khamis M. Auditory middle latency responses in children with specific language impairment. Eur Arch Otorhinolaryngol. 2012;269(6):1697-702. DOI: http://dx.doi.org/10.1007/ s00405-011-1901-7

29. Davids T, Valero J, Papsin BC, Harrison RV, Gordon KA. Effect of increasing duration of stimulation on he electrically evoked auditory brainstem and middle latency responses in pediatric cochlear implant users. J Otolaryngol Head Neck Surg. 2008;37(4):559-64. DOI: http://dx.doi.org/10.2310/7070.2008.0105

30. Gordon KA, Papsin BC, Harrison RV. Effects of cochlear implant use on the electrically evoked middle latency response in children. Hear Res. 2005;204(1-2):78-89. DOI: http://dx.doi.org/10.1016/j.heares.2005.01.003

31. Rodriguez HS, Corral M, Cadaveira F. Middle-latency auditory evoked potentials in children at high risk for alcoholism. Clin Neurophysiol. 2001;31(1):40-7. DOI: http://dx.doi.org/10.1016/S0987-7053(00)00241-0

32. Musiek FE. Probing brain function with acoustic stimuli. ASHA. 1989;31(8):100-6.

33. Misulis KE. Descrição geral dos potencias evocados. In: Misulis KE. Potencial evocado de Spehlmann: potenciais visuais, auditivo e somatossensitivo evocados no diagnóstico clínico. Rio de Janeiro: Revinter; 2003.

34. Schochat E, Rabelo CM, Loreti RCA. Sensitividade e especificidade do potencial de média latência. Rev Bras Otorrinolaringol. 2004;70(3):353-8. DOI: http://dx.doi.org/10.1590/S0034-72992004000300011

35. McGee T, Kraus N. Auditory development reflected by middle latency response. Ear Hear. 1996; 17(5): 419-29.

This article is distributed under the terms of the Creative Commons Attribution 4.0 International License (http://creativecommons.org/licenses/by/4.0/), which permits unrestricted use, distribution, and reproduction in any medium, provided you give appropriate credit to the original author(s) and the source, provide a link to the Creative Commons license, and indicate if changes were made. The Creative Commons Public Domain Dedication waiver (http://creativecommons.org/publicdomain/zero/1.0/) applies to the data made available in this article, unless otherwise stated.

\section{Resumo:}

Introdução: O potencial evocado auditivo de média latência é utilizado na avaliação de qualquer anomalia que possa comprometer as vias auditivas centrais, situadas entre o tronco encefálico e córtex auditivo primário.

Objetivo: Analisar os potenciais evocados auditivos de média latência em escolares.

Método: Esse estudo é descritivo transversal. Como procedimento foi realizado a audiometria tonal, e caso não fosse detectada nenhuma alteração, foi utilizado o equipamento portátil de potencial evocado auditivo Biologic's Evoked Potencial System (EP). O registro das respostas foi efetuado com eletrodos posicionados em C3 e C4 (hemisfério esquerdo e direito, respectivamente) em referência às orelhas A1 (lóbulo da orelha esquerda) e A2 (lóbulo da orelha direita), pareados ipsilateralmente e contralateralmente e terra em Fp (fronte), em duas etapas, alternando as estimulações das orelhas direita e esquerda.

Resultados: Neste estudo houve $100 \%$ de detectabilidade dos componentes $\mathrm{Na}, \mathrm{Pa}, \mathrm{Nb}$ e interamplitude $\mathrm{Na}-\mathrm{Pa}$. Foram comparadas diferentes derivações de eletrodo e não foi observada diferença significativa entre diferentes posições de eletrodos pesquisadas tanto para orelha direita quanto para orelha esquerda nesta população de estudo.

Conclusão: O exame de potencial evocado auditivo de média latência é estável e viável para faixa etária estudada independente da posição dos eletrodos.

Palavras-chave: Potencial evocado auditivo; respostas evocadas auditivas; crianças. 